\title{
Improving Students' Speaking Performance Through Vlog
}

\author{
Berlinda Mandasari', Dyah Aminatun² \\ Universitas Teknokrat Indonesia \\ berlinda@teknokrat.ac.id¹, Dyah_aminatun@teknokrat.ac.id²
}

\begin{abstract}
The shifting of English language learning from a conventional way to technologybased learning is famous nowadays. It is necessary to identify the effect of using technology towards the students' performance. One of technology that currently well-known is Vlog. This study aims at identifying the improvement of the students' performance after learning English using Vlog. The participants of this study is 40 students majoring English Education Department of Universitas Teknokrat Indonesia. They enrolled in Transactional Conversation subject where practicing English through vlog was carried out. The design of this research is quantitative study in which the researcher employed pre-test and post-test. The result of pre-test and post-test was analyzed by using statistics descriptive and statistics inferential (Mann-Whitney $U$ ). The result of analysis is there is significant improvement towards students' performance after learning English by using Vlog.
\end{abstract}

Keywords: Performance, Speaking, Vlog

\section{INTRODUCTION}

The terms of Industrial Revolution 4.0 is sounding globally nowadays. Specifically in Indonesia, it has been notified that technology innovations have emerged rapidly in all aspects of life. In education aspect, technology plays important role. It enables teachers and learners to carry out learning process. English language learning in higher education has also dealt with technology. A lot of lecturers use some devices, such as mobile device as a tool to support and facilitate teaching and learning environment. For example, the lecturer provides some mobile and web-based applications to facilitate students with collaborative classroom activities as a part of teaching process. These mobile and web application bring benefit for both lecturers and students. Instagram, a well-known mobile application, bring positive impact for students since it influences students' motivation, enggagement, and attitudes (Sari \& Wahyudin, 2019). Powtoon, a web application, helps students to improve their behavior in learning activity (Oktaviani, Mandasari, \& Maharani, 2020). Another web application that can be used as a tool in langauge learning is Memrise. It helps students to improve their English especially in English vocabulary. The easy access toward Memrise supports the successful of English learning (Aminatun \& Oktaviani,2019). On the other hand, Ted Talk is a web application that helps to enhance students' learning autonomy and improve students' listening ability (Puspita, D., \& Amelia, D., 2020). Lastly, WhatsApp, a mobil application had positive impact on students' attitude and motivation (Mandasari, B., \& Agusty, S. T. P). In short, these various models of

\section{ENGLISH EDUCATION}

Journal of English Teaching and Research 
mobile and web application which belong to part of technology enhancement have impact on students' improvement.

Furthermore, another technology innovation that is currently popular is Video Blog (Vlog) and YouTube channel. YouTube is a website that provides kinds of video clips, music videos, movie trailer, TV clips, video blogging, educational videos and short original videos (Jalaluddin, M., 2016). Gunelius (2018) also adds that vlog is a type of blog in which it is full of video content in it. Having a channel on YouTube, people can create vlog content then upload it to their channel. Thus, due to this phenomenon, teachers or learners also possibly can use vlog on YouTube or create their own to get them involved in the environment of the teaching learning process. This method can be interesting for students. It shows that technology innovation has brought education into a non-conventional ways. It also gives an exposure toward real-life situation and condition as authentic resources to learn English.

In English language learning, speaking skill is important to be taught. According to Burns (2012), It is notify that speaking skill involves cognitive process, physical, socio-cultural, and speakers' knowledge that take place in real situation and time. In Indonesian context, speaking English offers challenges since the Indonesian learners position English as foreign language. Not many English exposures are given in public. Ellis (2008) stated that having lack of English exposure and practice, students may need extra effort in mastering speaking skill.

The researchers have been teaching English at Universitas Teknokrat Indonesia for 4 years. During this time, the researchers have many experiences. It can be notified that teaching speaking skill has some problems. Firstly, the students may have little time in practicing speaking in the classroom. Within 100 minutes, the students are given 7 minutes to practice speaking based on the topic that has been agreed before. When it comes to calculation, there are only 14 students that will have chance to practice speaking. Meanwhile, the average number of students in speaking class is 24 students. It means that it takes more than a day to finish a topic delivered by students. Secondly, due to lack of practice, students have low motivation to practice speaking. It causes them not to achieve the component of speaking. Consequently, the students' scores decrease. Due to this problem, there must be a teaching innovation that leads students to be much more expressive and have more time to practice speaking English in order that they get accustomed to speak. Therefore, the students can improve their motivations which later increase their speaking performance.

In order to have a specific way to improve students speaking skill, technology innovation will be implemented. In this case, Vlog and YouTube channel are introduced to the students. The effect of implementing vlog in speaking skill will be discussed in this study. Vlog is chosen because it offers various experiences for students. It combines video, audio, pictures, text, informative content, interesting ways to deliver, expression, and emotion that are packed into one video which is shared to YouTube channel. Biel and Gatica-Perez (2010) stated that Vlog can be defined as a medium for communication in the form of online broadcasts which is created and posted. It may be in the form of video collections that consist of audiovisual life documentary and any of interesting content. Employing Vlog can be an alternative way to practice speaking English and strengthen self-confident. (Maulidah, 2018) found that there is a significant increase on students' speaking ability. Accessibility and a fun learning process carried out using Vlogs are proven 
to increase student enthusiasm for learning. In addition, learning English using a Vlog can provide a learning experience independently and interacting with the environment in real time. Some studies conducted to find out the effectiveness of Vlog in language learning. Hakim, M. I. A. A. (2019) revealed that vlog can improve students' English proficiency. Other research also revealed that Vlogs are very effective to increase students' satisfaction in learning English as Second language (Shih, R. C., 2010). Aydin (2014) revealed that vlog has positive impact in developing interaction between students and lecturers using target language. In accordance with its development, vlogs are designed to provide experience for users in expressing personal experience then shared in website network. Rakhmanina and Kusumaningrum (2017) found that students with high motivation tend to have higher speaking ability after implementing video blogging strategies compared to students with low motivation. Meanwhile, students with low motivation tend to succeed learning English using Expository strategy. Interaction was carried out during teaching and learning process. Considering the effectiveness of Vlog, the researchers are interested in conducting research by implementing this method to the students in speaking class. The researchers will evaluate the students' performance in learning English through vlog. So, this study will answer the research question: 1). Is there significant improvement toward students' performance of their speaking ability after learning English through Vlog?

\section{RESEARCH METHOD}

\section{Participant}

The participants of this research were 40 students majoring English Education study program Universitas Teknokrat Indonesia. They learnt Transactional Conversation on the second semester. They were chosen by using purposive sampling under several reasons. First, the students have YouTube channel and were assigned to watch Vlog frequently to improve their speaking ability. Second, the participants were eager to learn by using technology innovation. Third, Universitas Teknokrat Indonesia supports the learning process by using technology and has applied technology based learning inside or outside classroom. Thus, the students have a lot of chances to use some technology as an effort to support independent learning.

\section{Data Collection}

In order to measure the students' performance on their speaking, the researchers employed pre-test and post-test. The pre-test was done in the very beginning of the semester. Practically, the students were assigned to elaborate tourism places in Bali and Yogyakarta and traditional cuisines from both places. They were given 6 minutes to explain. They were allowed to bring any notes or show their power point presentation to support their presentation. The evaluation criteria include content, fluency, grammar, pronunciation and vocabulary. During the semester, the students took a trip to Bali and Yogyakarta. During the trip, the students were assigned to create their own vlog explaining tourism places and traditional cuisines from both places. They could create more than one vlog. They were assigned to be more expressive in delivering the content. They had to follow some stages to create an interesting vlog. According to Mandasari and Aminatun (2019), there are some stages done by students during vlogging. The stages

\section{ENGLISH EDUCATION}

Journal of English Teaching and Research 
|Volume: 5 | Number: 2 | October 2020| E-ISSN: 2503-4405|P-ISSN: 2580-3441|

include conceptualizing, brainstorming, articulating, monitoring, evaluating, reporting and uploading. As the semester ends, the students had to take final examination. They were given a post-test to measure their speaking performance. The instruction and the duration of speaking delivery were same as pre-test one. Then, the researcher got complete score of students' pre-test and post-test.

\section{Data Analysis}

Data analysis technique was done by processing the result of pre-test and post-test by using statistics analysis and statistics differential. The steps in analyzing the data were:

1. The researcher differs students' score of pre-test and post-test.

2. The researcher finds out the mean score of pre-test and post-test.

3. The researcher tests the normality distribution of the data.

The researchers find the result and interpret the data. Then, the reserchers present the data to answer research questions and find the discussion on it. Then, the researchers conclude the result of the research.

\section{RESULTS AND DISCUSSION}

In this study, the researcher wanted to measure the increase in students' performance, especially in speaking skill. Therefore, the researcher conducted a pre-test and a post-test. Furthermore, the test results are processed and analyzed. The results of pre-test and post-test data processing can be seen in Table 1.

\begin{tabular}{ccc}
\hline & Mean & DS \\
\hline Pre-test & 79.89 & 4.08 \\
\hline Post-test & 86.07 & 3.77 \\
\hline \multicolumn{2}{l}{ Table 1. Data Analysis of Pre-test and Post-test }
\end{tabular}

Table 1 shows that the average value of the post-test is greater than the value of pretest with range 6.18. The standard deviation of pre-test is 4.08 and post-test is 3.77 , meaning that there is not a large bias of the two mean values. To prove the allegation, a difference in the two average tests was carried out with the previous data normality test using the Kolmogorov Smirnov Test with the following results:

\begin{tabular}{cl}
\hline & Value of Sig. \\
\hline Pre-test & 0.007 \\
\hline Post-test & 0.046 \\
\hline
\end{tabular}

Table 2. Result of Normality Test by using Kolmogorov Smirnov

Based on the table 2, it can be seen that the value of Sig. (p-value) pre-test is 0.007 which is less than 0.05 and post-test is 0.046 which is more than 0.05 . It means that both groups of data are not normally distributed. Because the two data groups are not normally distributed, the two-difference test is continued by using the Non-Parametric Statistical Analysis using the Mann-Whitney U Test. The results of the Mann-Whitney U Test are pre-test and post-test as follows: 


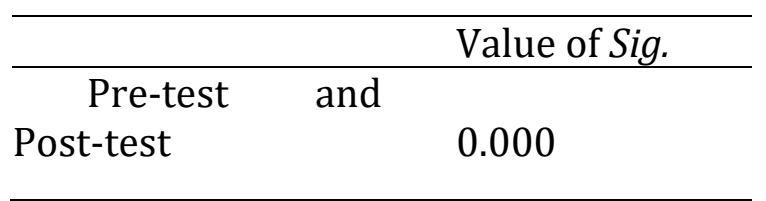

Table 3. Result of Mann-Whitney UTest

These results indicate that the value of Sig. (p-value) of 0.000 is less than 0.05 , which means that there are significant differences between the mean of pre-test and post-test. As a result, there is an influence of learning Transactional Conversation by using a video blog (vlog) to increase students' learning performance. In other words, there is a significant increase in students' performance during using Vlog as a medium of learning English especially in speaking skill.

Quantitatively, the research finding shows that there is significant difference between students' mean score of pre-test and post-test in which value of Sig. (pvalue) of 0.000 is less than 0.05 . It can be said that there is improvement on students' speaking ability viewed from the mean score of pre-test and post-test. This finding is supported by some studies conducted by some researchers. Watkins, J. (2012) states that vlog increases student talk time. It means more oral communication practice helps students improve mastery of new vocabulary and grammar, decrease shyness while bolstering confidence, and develop fluency. Teaching speaking through vlog also can help the students to be more actively participated in speaking to express what they think in their mind and see when they watch and listen the videos. It was confirmed by Anggraeni and Wulanjani (2017) who stated that video blogging helped students to be active in speaking class, increased students' willingness to participate in speaking class, improved students' ability to motivate themselves in speaking, made students' speaking class comfortable to participate and it challenged students to think critically. Another research that supports this research finding is a research conducted by Rahmawati, Harmanto, and Indriastuti (2018) which found that implementing vlog in speaking class was successful. Vlog helped students to improve their speaking ability. Furthermore, students' activeness and students' interest lead them to be more active and confident in practicing speaking. Consequently, it improved students' motivation to practice speaking English. Thus, the higher motivation they have, the more improvement of speaking skill they have.

Great interest and enthusiasm contribute on the successful of utilizing vlog in language learning. Provided with enjoyable learning atmosphere, students decrease their anxiety level since real-time communication in using vlog provide a comfortable and relaxing setting. Thus, it helps students to be more expressive and lead them to enjoy speaking without any pressure (Anil, 2016). Moreover, some students found advantages of using vlog. First, they may have an archive on their learning process that they can monitor the progress in each time they create a vlog. This archive provide data of students' improvement in terms of fluency, content, vocabulary, grammar, and pronunciation. It brings an important information on students' progress. Second, by providing real time setting, there are some valuable process that involve self-learning, self-evaluation, peer-learning, visual representation, professional develompement and technical capability. These process offer challenges to the students on how they can manage themselves to handle some technical problem and other issues related to language interference

\section{ENGLISH EDUCATION}

Journal of English Teaching and Research 
in real-time communication (Hung, 2011). Lastly, Vlog enables the students to practice more since they were given more time to prepare, practice, and evaluate. Interestingly, they can practice in an authentic setting that ease students deliver their ideas based on real place and time. Thus, it is recommended that the educators could apply some technology in the classroom and let students make use of it outside of the classroom where they are more convenient to practice speaking skill (Sari, 2017).

\section{CONCLUSION}

Based on the result and discussion above, it can be concluded that there is significant increase toward the students' performance after using Vlog in learning English especially in speaking skill. It was proven that the value of Sig. (p-value) is $0.000<0.05$, which means that there are significant differences between the mean of pre-test and post-test. Thus, it is suggested that Vlog can be one of an alternativetool to support English language teaching and learning. This study limits only on a narrow field .It is suggested that further research can uncover a broader area finding the impact of vlog toward students' self-regulated learning.

\section{REFERENCES}

Aminatun, D., \& Oktaviani, L. (2019). Memrise: Promoting Students' Autonomous Learning Skill through Language Learning Application. Metathesis: Journal of English Language, Literature, and Teaching, 3(2), 214223.DOI: $10.31002 /$ metathesis.v3i2.1982.

Anggraeni, C. W., \&Wulanjani, A. N. (2017).The Roles of TED Talks and Vlog in Enhancing Students' Activeness in Speaking Class. The 6th UNNES International Conference on ELTLT Proceedings, 113-116.

Anil, B. (2016).Top-Up Students Second Language Talk Time through Vlogs.Indonesian Journal of EFL and Linguistics, 1(2), 129143.DOI: http://dx.doi.org/10.21462/ijefll.v1i2.9.

Aydin, S. (2014).The Use of Blogs in Learning English as a Foreign Language.Mevlana International Journal of Education (MIJE), 4(1), 244259.

Biel, J.I., \& Gatica-Perez, D. (2010).Voices of Vlogging.Fourth International AAAI Conference on Weblogs and Social Media. 211-214.

Burns, A. (2012). Teaching Speaking: A Holistic Approach. New York: Cambridge University Press.

Ellis, R. (2008). Learner Beliefs and Language Learning.Asian EFL Journal, 10(4).

Gunelius, S. (2019). How to Create a Vlog. Retrieved from https://www.lifewire.com/what-is-a-vlog-3476285.

Hakim, M. I. A. A. (2019). The use of video in teaching English speaking. Research Methodology In Linguistics And Education, 4(2), 362.

Hung, S. T. (2011). Pedagogical applications of Vlogs: An investigation into ESP learners' perceptions. British Journal of Educational Technology, 42(5), 736746. DOI: https://doi.org/10.1111/j.1467-8535.2010.01086.x.

Jalaluddin, M. (2016). Using YouTube to enhance speaking skills in ESL classroom. English for Specific Purposes World, 17(50), 1-4.

Mandasari, B., \& Agusty, S. T. P. MOBILE LEARNING: THE IMPACT OF WHATSAPP USAGE IN ENGLISH LANGUAGE LEARNING. Section Editors. 
| Volume: 5 | Number: 2 | October 2020|E-ISSN: 2503-4405|P-ISSN: 2580-3441|

Mandasari, B., \& Aminatun, D. (2019). Vlog: A Tool to Improve Students' EnglishSpeaking Ability at University Level. Proceeding of the $3^{\text {rd Indonesian }}$ International Conference on Linguistics, Language Teaching, Literature and Culture, 245-254.

Maulidah, I. (2017). Vlog: The Mean to Improve Students' Speaking Ability. Proceedings of The International Conference on English Language Teaching (ICONELT). 145. 12-15. DOI: https://doi.org/10.2991/iconelt17.2018.3.

Oktaviani, L., Mandasari, B., \& Maharani, R. A. (2020). Implementing Powtoon To Improve Students'international Culture Understanding In English Class. Journal of Research on Language Education, 1(1), 19-25.

Puspita, D., \& Amelia, D. (2020). TED-TALK: A SUPPLEMENT MATERIAL TO PROMOTE STUDENTS'AUTONOMY IN LISTENING. ELTIN JOURNAL, Journal of English Language Teaching in Indonesia, 8(2), 91-102.

Rakhmanina, L., \& Kusumaningrum, D. (2017). The Effectiveness of Video Blogging in Teaching Speaking Viewed from Students' Learning Motivation. Fifth International Seminar onEnglish Language and Teaching (ISELT-5), 27-34.

Rahmawati, A., Harmanto, B., \& Indriastuti, N. R. (2018). The Use of Vlogging to Improve the Students' Speaking Skill. Edupedia, 2(1), 8795.DOI: $10.24269 /$ ed.v2i1.96.

Sari, F. M., \& Wahyudin, A. Y. (2019). Undergraduate Students' Perceptions Toward Blended Learning through Instagram in English for Business Class. International Journal of Language Education, 3(1), 6473.DOI: https://doi.org/10.26858/ijole.v1i1.7064.

Sari, P. (2017). Using Vlog in the Youtube Channel as a Means To Improve Students'Motivation and Confidence to Speak English in Intermediate 1 Level of LB-LIA Jambi. International Journal of Language Teaching and Education, 1(1), 38-44. DOI: https://doi.org/10.22437/ijolte.v1i1.4596.

Shih, R. C. (2010). Blended learning using video-based blogs: Public speaking for English as a second language students. Australasian Journal of Educational Technology, 26(6).

Watkins, J. (2012). Increasing student talk time through vlogging. Language Education in Asia, 3(2), 196-203. 